\title{
Salinity has no Effect on Polysomatic Pattern in Seedlings of Trifolium pratense and T. Repens
}

\author{
Valéria Kocová*, Dominika Bubanová, Albert RáKai, Vladislav KolarČIK \\ AND PaVol MÁrtonfi
}

\author{
Department of Botany, Institute of Biology and Ecology, P.J. Šafárik University, \\ Mánesova 23, 04001 Košice, Slovakia
}

Received March 6, 2017; revision accepted April 27, 2017

\begin{abstract}
Endopolyploidy is a condition of a cell containing reduplicated genetic material in its nucleus. Cells with the nuclei of different ploidy levels are often present within a single polysomatic organism. Endoreduplication is thus a modified cell cycle that omits cytokinesis and leads to chromatin replication in the endopolyploid cells. This study aimed to research the effect of salinity on endopolyploidy of Trifolium pratense and T. repens. Both species are important pasture legumes and belong to the genus Fabaceae with the well documented endopolyploidy occurence. Endopolyploidy levels in the seedlings treated with 0, 30, 60, 90 and $120 \mathrm{mM} \mathrm{NaCl}$ were investigated by flow cytometry. The seedling organs were evaluated during three ontogeny stages. The cytometric data plotted on a histogram showed the presence of $2 \mathrm{C}-16 \mathrm{C}$ nuclei in $T$. pratense and $2 \mathrm{C}-8 \mathrm{C}$ in $T$. repens. The hypothesis that salinity induces additional endocycles was not confirmed. Our results show that the distribution of nuclei among ploidy levels does not differ markedly between the treatment groups and the control ones. Additionally, only minor changes were observed among the endoreduplication indexes (EI) of plant organs after exposure to various salt concentrations. Endopolyploidy patterns within the salt-treated seedlings during ontogeny are similar to the controls. We suggest that endopolyploidy in Trifolium species is a conserved genetic trait, rather than an adaptation to salinity stress. The analyses of the roots of $T$. pratense at stage III show that with the increased concentrations of $\mathrm{NaCl}$ the length of roots decreased, but no evident changes in endopolyploidy occured.
\end{abstract}

Keywords: endopolyploidy, endoreduplication, Trifolium, salinity, stress

\section{INTRODUCTION}

Endopolyploidy is a common element of development and physiology of many Angiosperms. It is characterised by repeated multiplications of the genetic material within nuclei, which in turn do not undergo cytokinesis. Some plant groups attain a higher degree of endopolyploidization than others. Several factors are in play but taxonomic position is the major one (Barow and Meister, 2003; Bainard et al., 2012). Endopolyploidy levels are specific for some tissues and organs (Barow and Meister, 2003; Barow, 2006). The switch from mitosis to endoreduplication is irreversible and controlled by genetic, developmental and environmental signals (Maluszynska et al., 2013). Endopolyploidy was observed in the early development of plants, e.g., Chenopodium quinoa (Kolano et al., 2008), Beta vulgaris (Sliwinska and Lukaszewska, 2005) and Trifolium pratense (Straková et al., 2014). These works refer to endoreduplication as an essential part of normal development of seedlings of many plant species. In fact, the changes in endopolyploidy levels during ontogeny and the tissue-specific status of endopolyploidy indicate that endoreduplication is spatially and temporally regulated (Maluszynska et al., 2013).

The studies have revealed several roles of endopolyploidy, such as the control of organ growth (Sugimoto-Shirasu and Roberts, 2003; Cookson et al., 2006; Massonett et al., 2011), increasing of metabolism and utilization of the endocycle in stress-response pathways (Scholes and Paige, 2015). In endopolyploid plants, more endocycles are induced under the conditions of environmental stress, which can be provoked by abiotic and biotic factors such as light (Gendreau et al., 1998; Kudo and Mii, 2004; Kinoshita et al., 2008; Gegas et al., 2014), temperature (Engelen-Eigles et al., 2000), symbionts (Kondorosi and Kondorosi, 2004; Wildermuth, 2010), mycorrhizae (Bainard et al., 2011) and nematodes (de Almeida Engler and

\footnotetext{
*Corresponding author, email: valeria.kocova@upjs.sk
} 
Gheysen, 2013). Less attention has been paid to salt stress and associated water deficiency. Salt treatment induced endoreduplication in root cells of Sorghum bicolor or Allium cepa and in cali of Nicotiana bigelovii (Ceccarelli et al., 2006; Bennici et al., 2008). Water deficiency reduced the cell size of leaves of Arabidopsis thaliana and the kernel growth in maize and these were in correlation with an endopolyploidy level decrease (Cookson et al., 2006; Artlip et al., 1995). Scholes and Paige (2015) suggested that endoreduplication is employed as a plastic response to mitigate the effects of environmental stress. Plants typicaly respond to stress by increasing endopolyploidy beyond their 'normal' level.

Trifolium pratense $\mathrm{L}$. and $T$. repens $\mathrm{L}$. belong to the most important pasture legumes and are widely distributed in temperate regions throughout the world (Abberton, 2007). T. pratense is diploid $(2 \mathrm{n}=14)$ with $2 \mathrm{C}=0.9 \mathrm{pg}$ DNA and $T$. repens is tetraploid $(2 \mathrm{n}=32)$ with $2 \mathrm{C}=2.48 \mathrm{pg}$ DNA (Kocová et al., 2014). They are phylogenetically distinct: $T$. pratense belongs to the section Trifolium and $T$. repens to the section Trifoliastrum (Ellison et al., 2006). Recent studies showed that these two species are polysomatic in general; enhanced endopolyploidy levels were detected in T. pratense throughout its lifespan, from seeds to flower senescence (Kocová and Mártonfi, 2011; Kocová et al., 2014, Straková et al., 2014). Kocová et al. (2014) demonstrated that these two species have different endopolyploidy levels. Taxonomic affiliation seems to be the major factor impacting endopolyploidy in these species.

Salinity is a very destructive abiotic stress which limits crop productivity. It is a huge environmental problem in agricultural crop lands (Pitman and Läuchli, 2002; Munns and Gilliham, 2015; Shrivastana and Kumar, 2015). Many forage legumes are cultivated in irrigation areas with this problem. T. pratense has been determined as a highly salt-sensitive plant (Mandić et al., 2014). A decrease in germination and growth of seedlings in $T$. pratense was demonstrated with an increase of $\mathrm{NaCl}$ concentration (Asci, 2011; Mandić et al., 2014). Germination and subsequent development of seedlings are the crucial life phases of plants.

With regard to the role of endopolyploidy in early plant development under the salt stress conditions, the aim of this study was to estimate how endopolyploidy levels in individual organs of $T$. pratense and $T$. repens change during three ontogeny stages under application of various $\mathrm{NaCl}$ concentrations. Additionaly, we aimed to map the patterns of polysomaty in $T$. repens during the early phase of ontogeny - for the first time.

\section{MATERIAL AND METHODS}

\section{PLANT MATERIAL}

For the study we used seeds of $T$. pratense cultivar 'Nike' and T. repens 'Rivendel'. Twenty-five individual seeds were placed into Petri dishes with a piece of filter paper and $10 \mathrm{ml} \mathrm{NaCl}$ in the following concentrations: 0, 30, 60, 90 and $120 \mathrm{mM}$. The Petri dishes were sealed to prevent evaporation. The seeds were incubated in darkness at laboratory temperature (for 2 or 3 days). After the completion of germination (radicle protrusion), the seeds with the radicle penetrating the seed coat were transferred into plastic boxes with an openable cap and small holes at the top. $15 \mathrm{ml}$ of the solutions in the concentrations mentioned above were pipetted onto filter paper supported on glass beads, onto which the seedlings were placed. The boxes were stored in a controlled environment (light 12 hours / dark 12 hours). The plants were harvested for analyses after they underwent one of the three ontogenic stages: seedlings with the cotyledons fully opened (stage I), seedlings with the first leaves developed (stage II), seedlings with the second leaves developed (stage III). To estimate the effect of salinity on the organ size and endopolyploidy level, the length of $T$. pratense roots was measured in all salt treatments $(0,30,60,90$ and $120 \mathrm{mM})$ at stage III.

\section{FLOW CYTOMETRY}

Evaluation of endopolyploidy. Polysomaty of the organs was evaluated by flow cytometry. We prepared the samples from the following organs: root, hypocotyl, cotyledon, first leaf, petiole of the first leaf (first petiole), second leaf and petiole of the second leaf (second petiole). Every individual sample of fresh plant material was chopped in a Petri dish with a razor blade together with $1 \mathrm{ml}$ GPB (General purpose buffer $0.5 \mathrm{mM}$ spermin. $4 \mathrm{HCl}, 30 \mathrm{mM}$ sodium citrate, $20 \mathrm{mM}$ MOPS, $80 \mathrm{mM} \mathrm{KCl}, 20 \mathrm{mM}$ $\mathrm{NaCl}, 0.5 \%(\mathrm{v} / \mathrm{v})$ Triton X-100 pH 7.0) prepared according to Loureiro et al. (2007). The resulting mixture was filtered through $42 \mu \mathrm{m}$ nylon mesh filter. This suspension was supplemented with $10 \mu \mathrm{g} \cdot \mathrm{ml}^{-1}$ propidium iodide (PI) and $10 \mu \mathrm{g} \cdot \mathrm{ml}^{-1}$ RNase.

Usually 8-12 repetitions in $T$. pratense and 4-8 repetitions in T. repens per organ/ concentration/stage were analyzed. Lower numbers of duplicates or none were prepared in the cases when the lethal effect of salt was critical for the seedlings. All flow cytometric analyses were carried out by Partec CyFlow ML (Partec Gmbh, Münster, Germany) equipped with an argon-ion laser tuned at a wavelength of $532 \mathrm{~nm}$. This flow cytometer is housed at the Institute of Biological 
and Ecological Sciences, P.J. Šafárik University in Košice (Slovakia). The histograms were displayed on a logarithmic scale (x-axis). The resulting data were analyzed using FloMax Software 2.7 (Partec Gmbh, Münster, Germany). The measurements were made with an effort to reach approximately the same cv (\%) for all samples. The number of nuclei per individual peak was recorded on counts vs. PI fluorescence histograms. Then the percentage of nuclei of individual DNA levels in each sample was calculated and the acquired data were used to calculate the endoreduplication index (EI) (Bainard et al., 2012) according to the formula of Barow and Meister (2003). EI is averaging the number of endocycles undergone by each nucleus:

$$
\mathrm{EI}=\frac{\left(0 \times \mathrm{n}_{2 \mathrm{C}}+1 \times \mathrm{n}_{4 \mathrm{C}}+2 \times \mathrm{n}_{8 \mathrm{C}}+3 \times \mathrm{n}_{16 \mathrm{C}} \cdots\right)}{\left(\mathrm{n}_{2 \mathrm{C}}+\mathrm{n}_{4 \mathrm{C}}+\mathrm{n}_{8 \mathrm{C}}+\mathrm{n}_{16 \mathrm{C}} \cdots\right)}
$$

where $\mathrm{n}$ represents the number of nuclei of the corresponding ploidy level. The samples with EI less that 0.1 are not considered endopolyploid (Barow and Meister, 2003).

Determination of genome size. Genome sizes [pg] of T. pratense cultivar 'Nike' and T. repens 'Rivendel" were evaluated by flow cytometry. Preparation of the samples for genome size estimation was analogous to the protocol used for endopolyploidy measurements. The same flow cytometer was utilized. The first leaf of $T$. pratense was used and chopped together with the reference standard, Solanum lycopersicum cv. Stupické ( $2 \mathrm{C}=1.96$ pg DNA, Doležel et al., 1992). The first leaf of T. repens was evaluated with Zea mays CE-777 $(2 \mathrm{C}=5.43$ pg DNA, Lysák and Doležel, 1998). Nine repetitions were carried out for both species. The histograms were displayed on a linear scale (x-axis). The coefficients of variation (CV) of the GO/G1 peaks of both our species and the internal standards did not exceed $5 \%$. The data were analyzed with FloMax 2.7 (Partec Gmbh, Münster). DNA content was calculated according to Doležel and Bartoš (2005): Sample 2C DNA content $=2 \mathrm{C}$ sample peak mean $/ 2 \mathrm{C}$ standard peak mean $\times$ standard $2 \mathrm{C}$ DNA content $[\mathrm{pg}]$.

\section{STATISTICAL METHODS}

Exploratory data analysis was done in Microsoft Office Excel 2007. If the requirements of ANOVA were met, then ANOVA test (and Tukey's post hoc test for pairwise comparisons) was applied to test the mean difference of EI between treatments within specific organs. In few cases the requirements of ANOVA were not met and then Kruskal-Wallis test (with Mann-Whitney post hoc test with Bonferroni corrected $\mathrm{p}$ values to determine significance) was applied instead. These tests were performed in Past 3.14 (a significance level of 0.05 was used). Graphs were created in ggplot2 package (Wickham 2009) in $R$ (ver. 3.2.4) environment ( $R$ Core Team, 2016).

\section{RESULTS}

The genome size of $T$. pratense cultivar 'Nike' was estimated as $0.91 \pm 0.018 \mathrm{pg}$ (mean $\pm \mathrm{SD}$ ) and of T. repens 'Rivendel' as $2.22 \pm 0.022 \mathrm{pg}$.

The highest concentration of $\mathrm{NaCl}$ showed vast negative effects on Trifolium species; therefore, the results for the roots at stage III of $T$. pratense treated with the $120 \mathrm{mM}$ solution are not present here (Table 1 ). The seedlings of $T$. repens showed higher sensitivity to salinity than the seedlings of $T$. pratense. The results for $T$. repens at stage I include the data from $90 \mathrm{mM}$ and $120 \mathrm{mM}$ $\mathrm{NaCl}$ treatment, whereas the data for these concentrations at stage II and stage III are missing, since the plants were not able to grow in these $\mathrm{NaCl}$ concentrations (Table 2).

We studied the relationship between the organ size and the DNA content. The differences in the root length between the control and the salt treatments were obvious at stage III. The average lenght of $T$. pratense roots for $0 \mathrm{mM} \mathrm{NaCl}$ was $7.65 \pm 2.51 \mathrm{~cm}$ (mean $\pm \mathrm{SD}$ ), for $30 \mathrm{mM}$ $9.34 \pm 3.02 \mathrm{~cm}$, for $60 \mathrm{mM} 6.62 \pm 2.9 \mathrm{~cm}$, for $90 \mathrm{mM} 2.36 \pm 1.55 \mathrm{~cm}$ and for $120 \mathrm{mM}$ $0.84 \pm 0.35 \mathrm{~cm}$.

Developing organs of $T$. pratense contain cells with the nuclei of $2 \mathrm{C}, 4 \mathrm{C}, 8 \mathrm{C}$ and even $16 \mathrm{C}$ in some cases (Fig. 1). T. repens shows very low amounts of the $8 \mathrm{C}$ nuclei and the predominant $2 \mathrm{C}$ and $4 \mathrm{C}$ nuclei are present (Fig. 2). The seedlings of $T$. pratense and $T$. repens are polysomatic during the early stages of their ontogeny in both the control and the treatment groups. Exceptions were found for the first and the second leaves of $T$. pratense and the first and the second leaves and petioles of $T$. repens. These organs are considered non-endopolyploid (EI was under 0.1, Barow and Meister, 2003) (Tables 1, 2).

The effect of salinity on ploidy levels and the EI of the cells in developing organs can be discussed in two aspects. Firstly, we have to consider the effect of various concentrations of salt solution applied on individual organs compared to the control group. The second aspect deals with the long-term effect of salt concentration on EI of organs within the salt treatments during their ontogeny.

First aspect. In general, salt concentrations did not induce more endocycles in comparison to the control and only moderate changes in the percentage of nuclei were detected in salt-treated plants of Trifolium species. 

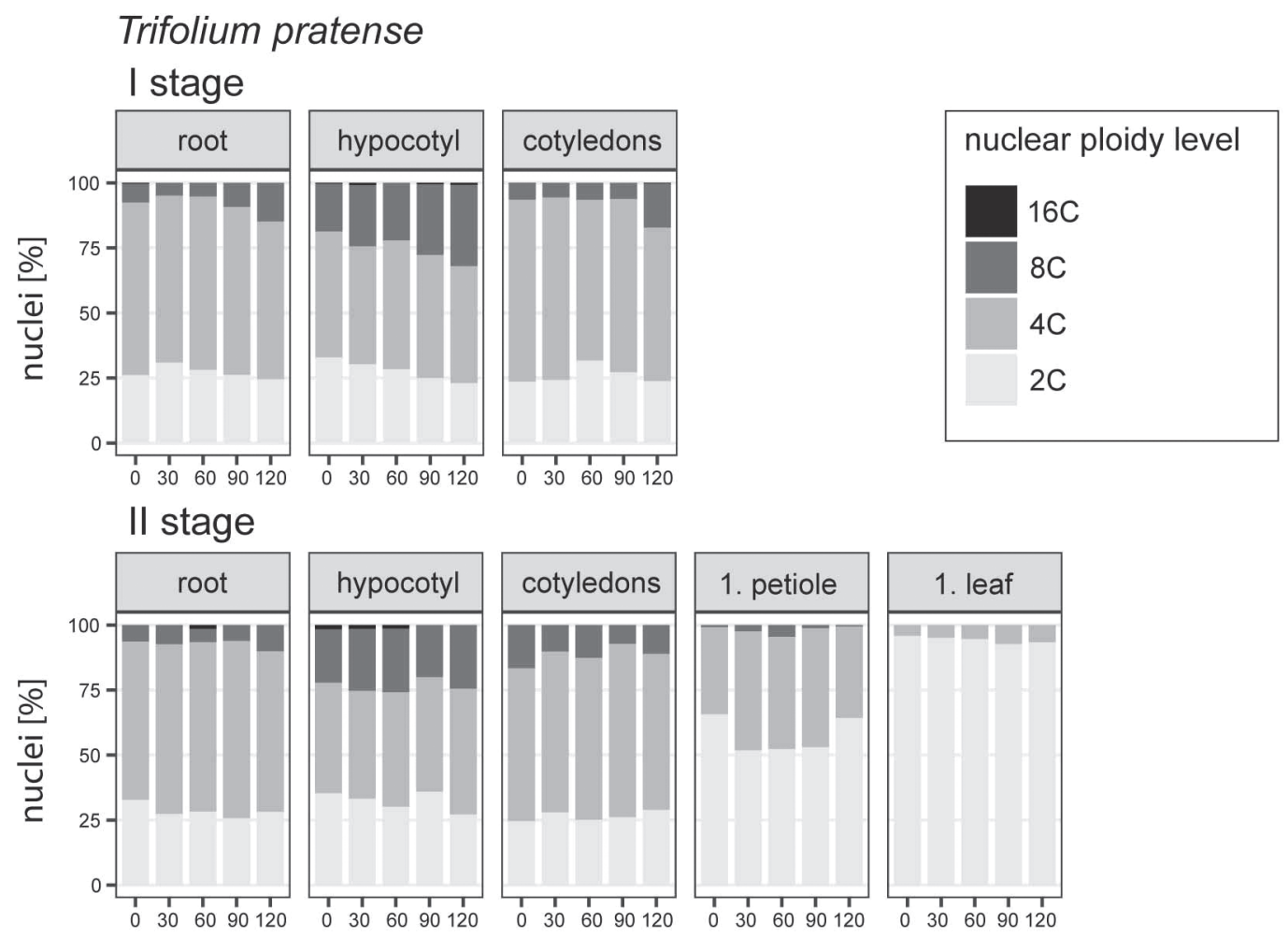

III stage
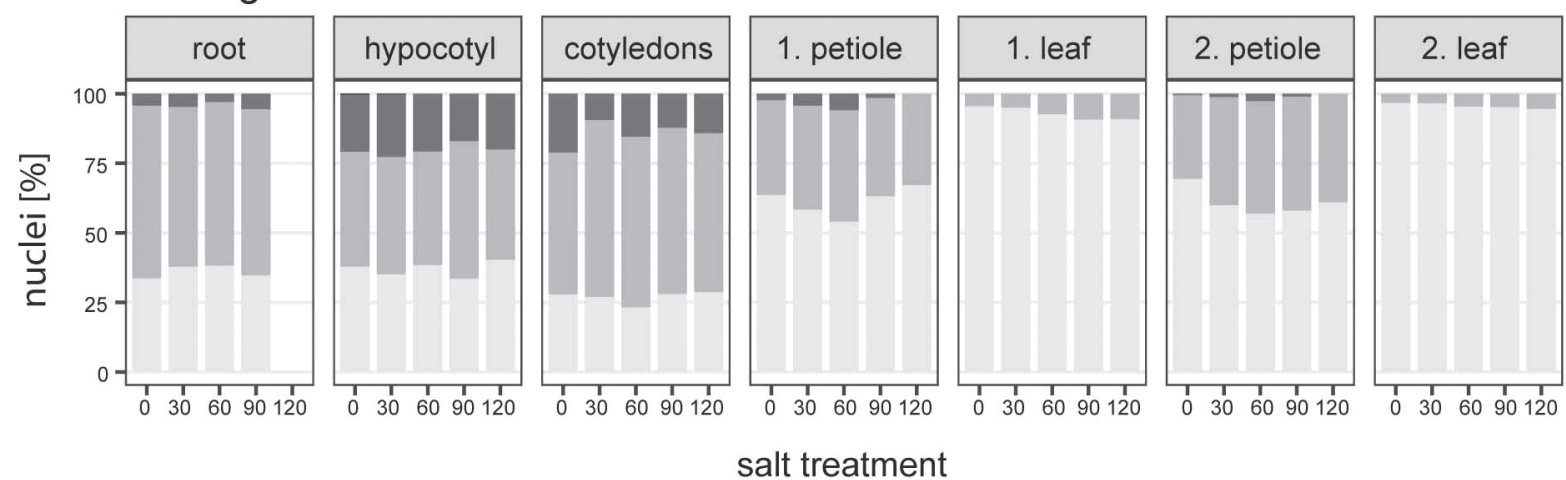

Fig. 1. Percentage of nuclei in organs of T. pratense seedlings within different $\mathrm{NaCl}$ concentrations [0-120 mM] during three ontogenetic stages.

Quantitatively significant differences for $T$. pratense were only found in the roots, the hypocotyls and the cotyledons at stage I, the first petioles and the first leaves at stage II and the first petiole at stage III (Table 1). The most significant difference in EI was found at stage I between the hypocotyls of $120 \mathrm{mM}(1.1)$ and $0 \mathrm{mM} \mathrm{NaCl}(0.86)$. In general, we observed only moderate increase in EI of the salt-treated roots (at stage II), hypocotyls (at stages I and II), first and second petioles, first and second leaves, compared to the control (Table 1). EI of the hypocotyls at stage III rose only with the application of $30 \mathrm{mM}$ salt solution. The cotyledons of the experimental plants in general (except for the $120 \mathrm{mM} \mathrm{NaCl}$ solution treatment at stage I) show lower EI values than those of the control group. Inspecting the first and the second petioles, we found EI slightly rising as a response to the salt treatment. EI of the leaves also increased, altough it still could not formally be considered endopolyploid. Similarly, EI of the first and the second leaves of T. repens increased with higher salt concentration, but always remained under 0.1. EI of the first petiole at stage II treated with $60 \mathrm{mM}$ salt solution increased above 0.1 with significant difference in comparison to 


\section{Trifolium repens}
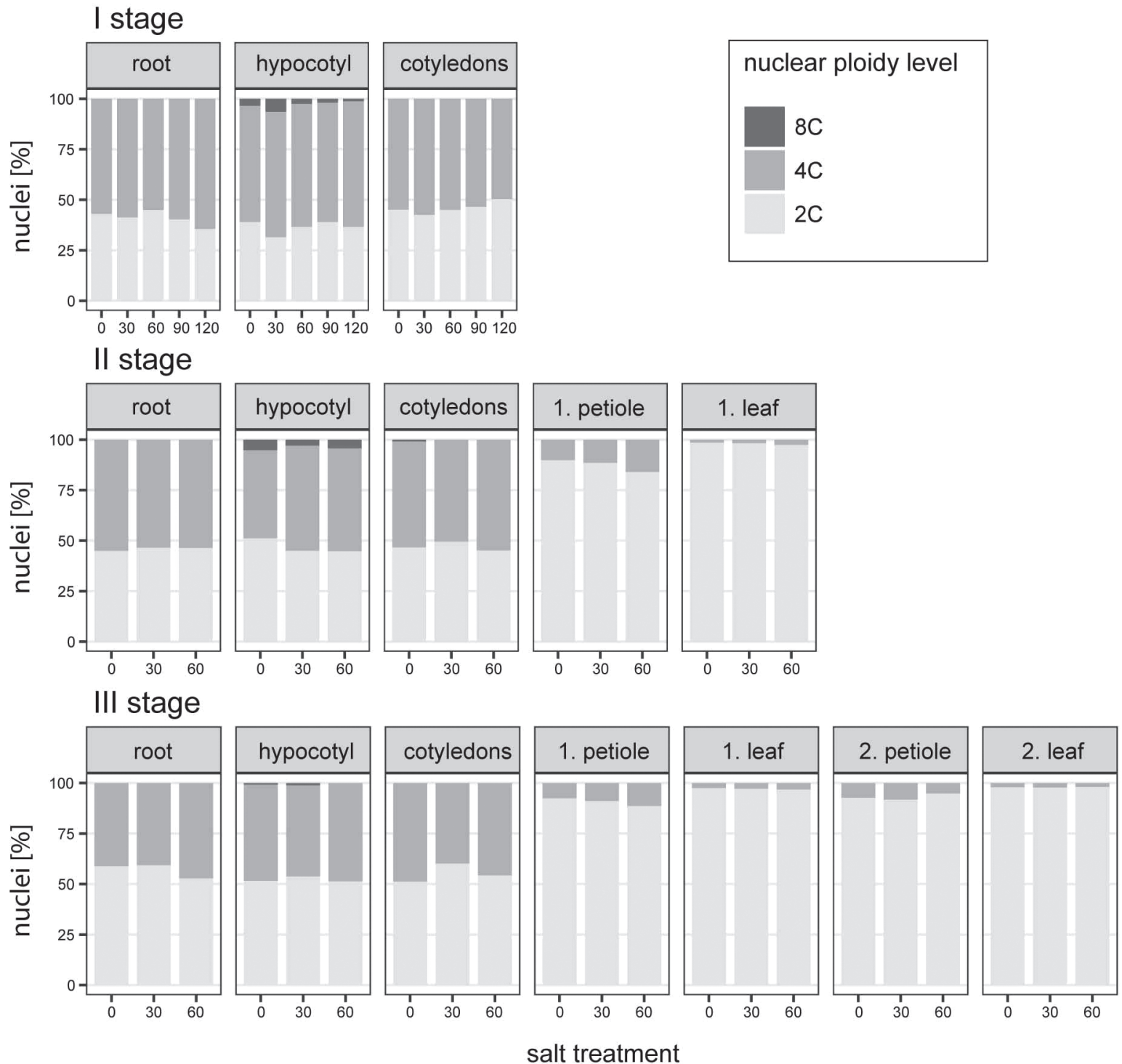

Fig. 2. Percentage of nuclei in organs of T. repens seedlings within different $\mathrm{NaCl}$ concentrations [0-120 mM] during three ontogenetic stages.

the control (ANOVA, $\mathrm{p}<0.05$; Table 2). Other organs of $T$. repens showed the salt-induced endopolyploidy patterns similar to $T$. pratense (Suppl. Fig. S1).

Second aspect. EI for both T. pratense and T. repens roots, hypocotyls and first petioles was predominantly decreasing during the ontogeny stages (Tables 1, 2). An opposite pattern was detected for the first leaves. A single difference between the species was detected: while endopolyploidy of the cotyledons in $T$. pratense increased with ontogeny, it decreased in $T$. repens (Tables 1, 2; Suppl. Fig. S1).
In general, the tendencies of EI are similar in $T$. pratense and $T$. repens, irrespective of the salt concentration or the ontogeny stage (Suppl. Fig. S1).

\section{DISCUSSION}

T. pratense is among the well known polysomatic species (Barow and Meister, 2003; Kocová et al., 2014; Straková et al., 2014). Here we document and prove, along with the previous study (Kocová et al., 2014), that $T$. repens is polysomatic at early 
TABLE 1. EI of organs of T. pratense seedlings within different $\mathrm{NaCl}$ concentrations [0-120 mM] during three ontogenetic stages [I-III].

\begin{tabular}{|c|c|c|c|}
\hline & I & II & III \\
\hline \multicolumn{4}{|c|}{ root } \\
\hline $0 \mathrm{mM}$ & $0.816 \pm 0.056 \mathrm{a}$ & $0.735 \pm 0.080 \mathrm{~ns}$ & $0.706 \pm 0.053 \mathrm{~ns}$ \\
\hline $30 \mathrm{mM}$ & $0.739 \pm 0.085 \mathrm{a}$ & $0.799 \pm 0.071$ & $0.668 \pm 0.076$ \\
\hline $60 \mathrm{mM}$ & $0.777 \pm 0.040 \mathrm{a}$ & $0.796 \pm 0.103$ & $0.646 \pm 0.125$ \\
\hline $90 \mathrm{mM}$ & $0.829 \pm 0.099 a b$ & $0.803 \pm 0.065$ & $0.708 \pm 0.182$ \\
\hline $120 \mathrm{mM}$ & $0.953 \pm 0.176 \mathrm{~b}$ & $0.818 \pm 0.145$ & - \\
\hline \multicolumn{4}{|c|}{ hypocotyl } \\
\hline $0 \mathrm{mM}$ & $0.860 \pm 0.050 \mathrm{a}$ & $0.883 \pm 0.127 \mathrm{~ns}$ & $0.832 \pm 0.140 \mathrm{~ns}$ \\
\hline $30 \mathrm{mM}$ & $0.947 \pm 0.116 \mathrm{ab}$ & $0.933 \pm 0.085$ & $0.879 \pm 0.110$ \\
\hline $60 \mathrm{mM}$ & $0.937 \pm 0.124 \mathrm{ab}$ & $0.969 \pm 0.099$ & $0.823 \pm 0.140$ \\
\hline $90 \mathrm{mM}$ & $1.030 \pm 0.141 \mathrm{ab}$ & $0.840 \pm 0.063$ & $0.835 \pm 0.097$ \\
\hline $120 \mathrm{mM}$ & $1.096 \pm 0.132 \mathrm{~b}$ & $0.972 \pm 0.150$ & $0.796 \pm 0.172$ \\
\hline \multicolumn{4}{|c|}{ cotyledons } \\
\hline $0 \mathrm{mM}$ & $0.828 \pm 0.080 \mathrm{ab}$ & $0.919 \pm 0.125 \mathrm{~ns}$ & $0.932 \pm 0.133 \mathrm{~ns}$ \\
\hline $30 \mathrm{mM}$ & $0.812 \pm 0.063 \mathrm{ab}$ & $0.821 \pm 0.074$ & $0.824 \pm 0.083$ \\
\hline $60 \mathrm{mM}$ & $0.748 \pm 0.088 \mathrm{a}$ & $0.874 \pm 0.086$ & $0.922 \pm 0.070$ \\
\hline $90 \mathrm{mM}$ & $0.788 \pm 0.056 \mathrm{a}$ & $0.810 \pm 0.043$ & $0.841 \pm 0.111$ \\
\hline $120 \mathrm{mM}$ & $0.899 \pm 0.080 \mathrm{~b}$ & $0.820 \pm 0.098$ & $0.854 \pm 0.073$ \\
\hline \multicolumn{4}{|c|}{ 1. petiole } \\
\hline $0 \mathrm{mM}$ & & $0.357 \pm 0.106 \mathrm{a}$ & $0.386 \pm 0.092 \mathrm{ab}$ \\
\hline $30 \mathrm{mM}$ & & $0.506 \pm 0.076 \mathrm{~b}$ & $0.458 \pm 0.096 \mathrm{ab}$ \\
\hline $60 \mathrm{mM}$ & & $0.521 \pm 0.072 \mathrm{~b}$ & $0.518 \pm 0.076 \mathrm{a}$ \\
\hline $90 \mathrm{mM}$ & & $0.481 \pm 0.098 \mathrm{~b}$ & $0.382 \pm 0.110 \mathrm{ab}$ \\
\hline $120 \mathrm{mM}$ & & $0.362 \pm 0.091 \mathrm{a}$ & $0.328 \pm 0.035 \mathrm{~b}$ \\
\hline \multicolumn{4}{|c|}{ 1. leaf } \\
\hline $0 \mathrm{mM}$ & & $0.042 \pm 0.006 \mathrm{a}$ & $0.045 \pm 0.020 \mathrm{~ns}$ \\
\hline $30 \mathrm{mM}$ & & $0.049 \pm 0.014 \mathrm{ab}$ & $0.050 \pm 0.027$ \\
\hline $60 \mathrm{mM}$ & & $0.053 \pm 0.015 a b$ & $0.073 \pm 0.019$ \\
\hline $90 \mathrm{mM}$ & & $0.073 \pm 0.019 b$ & $0.093 \pm 0.049$ \\
\hline $120 \mathrm{mM}$ & & $0.066 \pm 0.025 \mathrm{ab}$ & $0.091 \pm 0.028$ \\
\hline \multicolumn{4}{|c|}{ 2. petiole } \\
\hline $0 \mathrm{mM}$ & & & $0.311 \pm 0.116 \mathrm{~ns}$ \\
\hline $30 \mathrm{mM}$ & & & $0.412 \pm 0.088$ \\
\hline $60 \mathrm{mM}$ & & & $0.457 \pm 0.108$ \\
\hline
\end{tabular}


TABLE 1. continued

\begin{tabular}{ccc}
\hline \hline & I & II \\
\hline $90 \mathrm{mM}$ & III & $0.430 \pm 0.104$ \\
\hline $120 \mathrm{mM}$ & $\mathbf{2 . 1 \text { leaf }}$ \\
\hline $0 \mathrm{mM}$ & $0.390 \pm 0.048$ \\
\hline $30 \mathrm{mM}$ & $0.032 \pm 0.006 \mathrm{~ns}$ \\
\hline $60 \mathrm{mM}$ & $0.034 \pm 0.008$ \\
\hline $90 \mathrm{mM}$ & $0.046 \pm 0.018$ \\
\hline $120 \mathrm{mM}$ & $0.048 \pm 0.017$ \\
\hline
\end{tabular}

Values are mean of EI \pm standard deviation, different letters indicate homogeneous groups revealed by Tukey's or Mann-Whitney pairwise post hoc tests, if ANOVA and Kruskal-Wallis test have indicated significant differences in EI between $\mathrm{NaCl}$ concentrations. ns $=$ no significant difference

and late development stages, but it does not reach the same endopolyploidy level as $T$. pratense. It is clear that polysomaty is a permanent trait throughout the whole life cycle of this crop species.

The level of endopolyploidy present in individual organs of seedlings is important with regards to their differentiation and development (Scholes and Paige, 2015). Scholes and Paige (2015) suggest that plants use endoreduplication as an adaptive mechanism to mitigate the effects of stress. Based on Scholes and Paige (2015) and with the insight into the impact of salinity on endoreduplication by Bennici et al. (2008) and Ceccarelli et al. (2006), we expected to find considerable changes in endopolyploidy levels in Trifolium seedlings.

The study of Ceccarelli et al. (2006) showed that an increased presence of salt noticeably enhanced endoreduplication in roots of Sorghum bicolor. Specifically, root hairs showed an increase in the amount of $8 \mathrm{C}$ nuclei and additional $16 \mathrm{C}$ and $32 \mathrm{C}$ nuclei were present. However, the proportions of the nuclei in the leaves and the vascular cylinder of Sorghum bicolor were similar to the controls (Ceccarelli et al., 2006). In the salt-treated root differentiation zone of Allium cepa, an increase of $4 \mathrm{C}$ and aditional $8 \mathrm{C}$ and $16 \mathrm{C}$ nuclei were observed (Bennici et al., 2008). With an increased $\mathrm{NaCl}$ concentration, higher DNA contents were recorded in Nicotiana bigelovii (Bennici et al., 2008). However, our results suggest that increased salinity does not affect endoreduplication in Trifolium organs of seedlings as extensively as expected. Both the control and the salt-treated plants of Trifolium species showed the same ploidy level distribution, meaning that the heightened salinity did not induce aditional endocycles. Aditionally, only minor differences in the distribution of nuclei among ploidy levels induced by the salt treatment were observed (Fig. 1, 2). These results show that excessive salinity does not cause significant changes in the ploidy distribution within the developing Trifolium seedlings (Fig. 1, 2).

We found slight (statistically insignificant) increases in EI for some organs caused by the application of salt solution to the growth medium (Tables 1,2). This may serve the young seedlings as a means of preservation of the integrity and the function of plant organs. Consulting our results, we propose that endopolyploidy of Trifolium species is more likely conditioned by genetic prerequisites while less susceptible to the stress factor. Referring to the study of Ceccarelli et al. (2006), the saltinduced endoreduplication occured in the saltadapted Sorghum bicolor cv. 610, while remaining unchanged in another genotype of S. bicolor (Dk 34-Alabama), incompetent for salt adaptation. The studies of Bennici et al. (2008) and Ceccarelli et al. (2006) together with our results suggest that the plasticity of endoreduplication is a genomic response to high salinity. It also exhibits tissue and species specificity and variation related to genetic characteristics of the studied plant.

In general, the patterns of endopolyploidy during the ontogeny stages within the organs of $T$. pratense and T. repens treated with salt are similar to the control group and correspond with the results of Straková et al. (2014). Again, this suggests the low impact of salinity on endopolyploidy of both species. However, ambiguous values of EI were obtained from the analyses of cotyledons of $T$. pratense (Table 1). The average EI of the cotyledons treated with $60 \mathrm{mM}$ salt solution rose up from 0.75 at stage I to 0.92 
TABLE 2. EI of organs of T. repens seedlings within different $\mathrm{NaCl}$ concentrations [0-120 mM] during three ontogenetic stages [I-III].

\begin{tabular}{|c|c|c|c|}
\hline & I & II & III \\
\hline \multicolumn{4}{|c|}{ root } \\
\hline $0 \mathrm{mM}$ & $0.569 \pm 0.083 \mathrm{~ns}$ & $0.551 \pm 0.051 \mathrm{~ns}$ & $0.412 \pm 0.076 \mathrm{~ns}$ \\
\hline $30 \mathrm{mM}$ & $0.587 \pm 0.049$ & $0.534 \pm 0.082$ & $0.407 \pm 0.040$ \\
\hline $60 \mathrm{mM}$ & $0.550 \pm 0.067$ & $0.535 \pm 0.074$ & $0.471 \pm 0.104$ \\
\hline $90 \mathrm{mM}$ & $0.597 \pm 0.057$ & - & - \\
\hline $120 \mathrm{mM}$ & $0.644 \pm 0.025$ & - & - \\
\hline \multicolumn{4}{|c|}{ hypocotyl } \\
\hline $0 \mathrm{mM}$ & $0.644 \pm 0.078 \mathrm{~ns}$ & $0.540 \pm 0.070 \mathrm{~ns}$ & $0.492 \pm 0.114 \mathrm{~ns}$ \\
\hline $30 \mathrm{mM}$ & $0.749 \pm 0.104$ & $0.579 \pm 0.070$ & $0.473 \pm 0.100$ \\
\hline $60 \mathrm{mM}$ & $0.658 \pm 0.095$ & $0.595 \pm 0.096$ & $0.486 \pm 0.050$ \\
\hline $90 \mathrm{mM}$ & $0.628 \pm 0.081$ & - & - \\
\hline $120 \mathrm{mM}$ & $0.645 \pm 0.102$ & - & - \\
\hline \multicolumn{4}{|c|}{ cotyledons } \\
\hline $0 \mathrm{mM}$ & $0.549 \pm 0.075 \mathrm{~ns}$ & $0.542 \pm 0.040 \mathrm{~ns}$ & $0.487 \pm 0.042 \mathrm{~ns}$ \\
\hline $30 \mathrm{mM}$ & $0.575 \pm 0.112$ & $0.504 \pm 0.109$ & $0.400 \pm 0.095$ \\
\hline $60 \mathrm{mM}$ & $0.550 \pm 0.057$ & $0.548 \pm 0.082$ & $0.457 \pm 0.031$ \\
\hline $90 \mathrm{mM}$ & $0.535 \pm 0.209$ & - & - \\
\hline $120 \mathrm{mM}$ & $0.496 \pm 0.161$ & - & - \\
\hline \multicolumn{4}{|c|}{ 1. petiole } \\
\hline $0 \mathrm{mM}$ & & $0.101 \pm 0.023 \mathrm{a}$ & $0.075 \pm 0.017 \mathrm{~ns}$ \\
\hline $30 \mathrm{mM}$ & & $0.114 \pm 0.043 \mathrm{a}$ & $0.088 \pm 0.037$ \\
\hline $60 \mathrm{mM}$ & & $0.160 \pm 0.042 b$ & $0.113 \pm 0.040$ \\
\hline $90 \mathrm{mM}$ & & - & - \\
\hline $120 \mathrm{mM}$ & & - & - \\
\hline \multicolumn{4}{|c|}{ 1. leaf } \\
\hline $0 \mathrm{mM}$ & & $0.014 \pm 0.011 \mathrm{~ns}$ & $0.024 \pm 0.019 \mathrm{~ns}$ \\
\hline $30 \mathrm{mM}$ & & $0.017 \pm 0.008$ & $0.028 \pm 0.027$ \\
\hline $60 \mathrm{mM}$ & & $0.025 \pm 0.009$ & $0.032 \pm 0.021$ \\
\hline $90 \mathrm{mM}$ & & - & - \\
\hline $120 \mathrm{mM}$ & & - & - \\
\hline \multicolumn{4}{|c|}{ 2. petiole } \\
\hline $0 \mathrm{mM}$ & & & $0.073 \pm 0.058 \mathrm{~ns}$ \\
\hline $30 \mathrm{mM}$ & & & $0.082 \pm 0.025$ \\
\hline
\end{tabular}


TABLE 2. continued

\begin{tabular}{|c|c|c|c|}
\hline & I & II & III \\
\hline $60 \mathrm{mM}$ & & & $0.051 \pm 0.048$ \\
\hline $90 \mathrm{mM}$ & & & - \\
\hline $120 \mathrm{mM}$ & & & - \\
\hline \multicolumn{4}{|c|}{ 2. leaf } \\
\hline $0 \mathrm{mM}$ & & & $0.020 \pm 0.010 \mathrm{~ns}$ \\
\hline $30 \mathrm{mM}$ & & & $0.022 \pm 0.023$ \\
\hline $60 \mathrm{mM}$ & & & $0.019 \pm 0.013$ \\
\hline $90 \mathrm{mM}$ & & & - \\
\hline $120 \mathrm{mM}$ & & & - \\
\hline
\end{tabular}

Values are mean of EI \pm standard deviation, different letters indicate homogeneous groups revealed by Tukey's or Mann-Whitney pairwise post hoc tests, if ANOVA and Kruskal-Wallis test have indicated significant differences in EI between NaCl concentrations. ns = no significant difference

at stage III. Very high EI of the cotyledons is most likely caused by a strong metabolic activity of these organs (Maluszynska et al., 2013) further utilized for primary nutrition processes during the salinity stress.

According to several studies, cell size is positively correlated to endopolyploidy (Barow et al., 2006; Sugimoto-Shirasu and Roberts, 2003). It has been speculated that cell division, cell expansion and endoreduplication work on organ growth in conjunction with each other. Endoreduplication can aid organ development through cell expansion. Massonnet et al. (2011) describe the crucial role of endoreduplication in the leaf growth. Another study shows how shading and water deficit lead to a reduced leaf volume, lower cell numbers and endopolyploidy (Cookson et al., 2006). We elaborated on this hypothesis and found out that the lenght of roots at stage III exposed to salt varied greatly: $30 \mathrm{mM}$ treated roots were longer than the control; in all other instances the lenght of the roots decreased with the treatment, from $30 \mathrm{mM}$ to $120 \mathrm{mM}$. When considering the impact of various treatments on ploidy levels present in the roots, our results show the same $2 \mathrm{C}, 4 \mathrm{C}$ and $8 \mathrm{C}$ nuclei proportions as in the control group. It suggests that salt stress affects the growth of roots negatively, while at the same time the proportions of $2 \mathrm{C}, 4 \mathrm{C}$ and $8 \mathrm{C}$ nuclei are maintained. It means that the differences in the root size are apparently caused by an overall lower growth rate (the decrease in cell division rate) as the salt treatment intensifies, rather than a physiological effect of endopolyploidy changes. De Veylder et al. (2011) describe how a plant with an elevated percentage of higher-ploidy cells can use the growth potential of these endopolyploid cells to compensate for the decreased cell number caused by external factors. However, it is not our case. It seems that the roots of $T$. pratense prefer to maintain constant endopolyploidy levels and the effect of salt treatment is directly translated into the hindered tissue development and the inhibited elongation of roots without any compensation on the plant's part.

\section{CONCLUSION}

Mandić et al. (2014) determined that T. pratense is a highly salt-sensitive plant, especially during germination and early seedling growth stages. Our results dealing with $T$. pratense and $T$. repens show that Trifolium species may not be salt-competent, because the plants conserve default ploidy levels in their organs despite the salt stress. This proves that endopolyploidy in $T$. pratense and $T$. repens is genetically fixed. Some of the detected changes in EI could stand for an attempted adaptation to salt, since maintaining of the function of the studied organs is crucially important. To sum up, salt stress may induce endopolyploidy changes in Trifolium species, but only to a negligible extent. We suggest that in the case of the studied species, the genetic predisposition for a certain polysomatic pattern outweighs its induction by stress. 


\section{AUTHORS' CONTRIBUTIONS}

VKoc conducted and coordinated the study. VKoc carried out flow cytometry analyses. DB participated in the experimental work. VKol analyzed the data statistically. VKoc and AR wrote the manuscript. PM conceptualized the study and edited the manuscript.

All authors have read and approved the final manuscript. The authors declare no conflict of interest.

\section{ACKNOWLEDGEMENTS}

Support for this research was provided by the VEGA Grant Agency (Slovakia) no. 1/0163/15.

The authors thank Dr. Lenka Mártonfiová for English language correction.

\section{REFERENCES}

ABBERTON MT. 2007. Interspecific hybridization in the genus Trifolium. Plant Breeding 126: 337-342.

ARtlip TS, Madison JT, and Setter TL. 1995. Water deficit in developing endosperm of maize: cell division and nuclear DMA endoreduplication. Plant, Cell and Environment 18: 1034-1040.

Asci OO. 2011. Salt tolerance in red clover (Trifolium pratense L.) seedlings. African Journal of Biotechnology 10: 8774-8781.

BAinaRd LD, Bainard JD, NEWMASTER SG, and KliRONOMOS JN. 2011. Mycorrhizal symbiosis stimulates endoreduplication in angiosperms. Plant, Cell and Environment 34: 1577-1585.

BAINARD JD, BAINARD LD, HENRY TA, and FAZEKAS AJ. 2012. A multivariate analysis of variation in genome size and endoreduplication in angiosperms revelas strong phylogenetic signal and association with phenotypic traits. New Phytologist 196: 1240-1250.

BARow M. 2006. Endopolyploidy in seed plants. BioEssays 28: 271-281.

BARow M, and Meister A. 2003. Endopolyploidy in seed plants is differently correlated to systematics, organ, life strategy and genome size. Plant, Cell and Environment 26: 571-584.

Bennici A, Caceres ME, Cionini G, and Cionini PG. 2008. A DNA cytophotometric study of salt adaptation in Allium cepa and Nicotiana bigelovii. Caryologia 61: 176-181.

Ceccarelli M, Santantonio E, Marmottini F, Amzallag GN, and Cionini PG. 2006. Chromosome endoreduplication as a factor of salt adaptation in Sorghum bicolor. Protoplasma 227: 113-118.

Cookson SJ, RadzieJwoski A, and Granier CH. 2006. Cell and leaf size plasticity in Arabidopsis: what is the role of endoreduplication? Plant, Cell and Environment 29: 1273-1283. de Almeida Engler J, and Gheysen G. 2013. Nematode-induced endoreduplication in plant host cells: why and how? Molecular Plant-Microbe Interactions 26: 17-24.

De Veylder L, LARKin J C, and SchnitTger A. 2011. Molecular control and function of endoreplication in development and physiology. Trends in Plant Science 16: 624-634.

DOLEŽEL J, and BARTOŠ J. 2005. Plant DNA flow cytometry and estimation of nuclear genome size. Annals of Botany 95: 99-110.

DoležEl J, SGorbati S, and Lucretti S. 1992. Comparison of three DNA fluorochromes for flow cytometric estimation of nuclear DNA content in plants. Physiologia Plantarum 85: 625-631.

Ellison NW, Liston A, Steiner JJ, Williams WM, and Taylor NL. 2006. Molecular phylogenetics of the clover genus (Trifolium-Leguminosae). Molecular Phylogenetetics and Evolution 39: 688-705.

Engelen-eigles G, Jones RJ, and Phillips RL. 2000. DNA endoreduplication in maize endosperm cells: the effect of exposure to short-term high temperature. Plant, Cell and Environment 23: 657-663.

Gegas VC, Wargent JJ, Pesguet E, Grangvist E, Paul D, and Doonan JH. 2014. Endopolyploidy as a potential alternative adaptive strategy for Arabidopsis leaf size variation in response to UV-B. Journal of Experimental Botany 65: 2757-2766.

Gendreau E, Höfte H, Grandjean O, Brown S, and Traas J. 1998. Phytochrome controls the number of endoreduplication cycles in the Arabidopsis thaliana hypocotyl. Plant Journal 13: 221-230.

Kinoshita I, Sanbe A, and Yokomura E-ITI. 2008. Difference in light-induced increase in ploidy level and cell size between adaxial and abaxial epidermal pavement cells of Phaseolus vulgaris primary leaves. Journal of Experimental Botany 59: 1419-1430.

Kocová V, and MÁRTONFi P. 2011. Endopolyploidy in Trifolium pratense L. Caryologia 64: 419-426.

Kocová V, KolarčIK V, Straková N, and Mártonfi P. 2014. Endopolyploidy patterns in organs of Trifolium species (Fabaceae). Acta Biologica Cracoviensia Series Botanica 56: 111-120.

Kolano B, Siwinska D, and MaluszynsKa J. 2008. Endopolyploidy patterns during development of Chenopodium quinoa. Acta Biologica Cracoviensia Series Botanica 51: 85-92.

Kondorosi E, and Kondorosi A. 2004. Endoreduplication and activation of the anaphase promoting complex during symbiotic cell development. FEBS Letters 567: 152-157.

Kudo N, and Mir M. 2004. Endoreduplication cycles during hypocotyl growth of cabbage (Brassica oleracea L.) under light and dark conditions. Plant Biotechnology 21: 283-287.

Loureiro J, Rodriguez E, Doležel J, and SAntos C. 2007. Two new nuclear isolation buffers for plant DNA flow cytometry: A test with 37 species. Annals of Botany 100: 875-888.

LYSÁK MA, and DoležEL J. 1998. Estimation of nuclear DNA content in Sesleria (Poaceae). Caryologia 52: 123-132.

MaluszynsKa J, Kolano B, and SAs-Nowosielska H. 2013. Endopolyploidy in plants. In: Leitch IJ, Greilhuber J, Dolezel J, and Wendel J [eds.], Plant Genome Diversity, 
vol. 2. Physical Structure, Behaviour and Evolution of Plant Genomes, 99-119. Springer-Verlag, Wien.

Mandić V, KRnJaja V, BiJelić Z, Tomić Z, Simić A, Ružić Muslić D, and Stanojković A. 2014. Genetic variability of red clover seedling in relation to salt stress. Biotechnology in Animal Husbandry 30: 529-538.

Massonnet C, Tisne' S, Radziejwoski A, Vile D, De Veylder L, Dauzat M, and Granier CH. 2011. New insights into the control of endoreduplication: Endoreduplication could be driven by organ growth in Arabidopsis leaves. Plant Physiology 157: 2044-2055.

Munns R and Gilliham M. 2015. Salinity tolerance of crops what is the cost? New Phytologist 208: 668-673.

Pitman MG, and LäUChLI A. 2002. Global impact of salinity and agricultural ecosystems. In: Läuchli A, Lüttge U [eds.], Salinity: Environment - Plants - Molecules, 3-20. Kluwer Academic Publishers, The Netherlands.

R Core TeAm. 2016. R: A language and environment for statistical computing. R Foundation for Statistical Computing, Vienna, Austria. URL https://www.R-project.org/.
Scholes DR, and PAIGE KN. 2015. Plasticity in ploidy: a generalized response to stress. Trends in Plant Science 20: 165-175.

Shrivastava P, and Kumar R. 2015. Soil salinity: A serious environmental issue and plant growth promoting bacteria as one of the tools for its alleviation. Saudi Journal of Biological Sciences 22: 123-131.

SLIWINSKa E, and LuKASzEWsKa E. 2005. Polysomaty in growing in vitro sugar-beet (Beta vulgaris L.) seedlings of different ploidy level. Plant Science 168: 1067-1074.

Straková N, Kocová V, KolarčIK V, and Mártonfi P. 2014. Endopolyploidy in organs of Trifolium pratense $\mathrm{L}$. in different ontogenetic stages. Caryologia 67: 116-123.

Sugimoto-Shirasu K, and RoBerTs K. 2003. "Big it up": endoreduplication and cell-size control in plants. Current Opinion in Plant Biology 6: 544-553.

Wiскнам H. 2009. ggplot2: Elegant Graphics for Data Analysis. Springer-Verlag, New York.

WiLDERMUTH MC. 2010. Modulation of host nuclear ploidy: a common plant biotroph mechanism. Current Opinion in Plant Biology 13: 449-458. 